\title{
The long shadow of dictatorships beyond the near East: authoritarian legacies and citizens' democratic attitudes in Indonesia, Myanmar and Thailand
}

\author{
Giovanna Maria Dora Dore
}

The Johns Hopkins University, Baltimore MD, USA

Following the end of WWII, authoritarian leaders or authoritarian regimes ruled many countries in Asia, enjoying almost absolute control over the party, military, and state apparatuses. Starting in mid-1980, the progressive weakening of several autocracies provided a catalyst for democratization in the region. Yet, the movement toward democracy has remained limited, with only eight countries becoming electoral democracies out of more than 60 that became democratic around the world. Using original national-level survey data, this article investigated the possible impacts of authoritarian legacies on citizens' attitudes towards democratic rule in Indonesia, Myanmar, and Thailand, and also attempted a comparison with countries in the middle East and North Africa. It found that, across the three countries, citizens lack a forbetter-or-worse commitment to democratic rule and see it "as a second-best alternative, or as a lesser evil by comparison with a plurality of undemocratic alternatives", that even those who wholeheartedly support democratic rule appear to lack many of the political strengths and underlying civic habits needed for the development of a lasting democratic political culture, and that countries' specific combinations of a small numbers of predictors explain citizens' support for democratic rule in Indonesia, Myanmar and Thailand.

\section{Introduction}

Many countries in Asia are not making a decisive move toward democracy. They remain in a democratization gray area, with weak political institutions and limited citizens' political engagement. Since 1974, eight countries in Asia have become electoral democracies out of more than 60 countries that transitioned to democracy around the 
world. ${ }^{1}$ A lively, although sprawling, debate is in progress to understand why democratization seems to be so difficult in Asia. Whether qualitatively or quantitatively, the discussion spans from overall desirability of/ support for democracy in in the region ${ }^{2}$, to economic development as a trigger for democratic transition ${ }^{3}$, to the cultural foundations of Asian societies and their influence on the regions' diverse political systems ${ }^{4}$, to Asian "exceptionalism." relevance/impacts of authoritarian legacies on democratization in spite of the fact that with the exception of Japan, following the end of World War II, all the countries in the region have had, or continue to have, some experience of authoritarian rule. ${ }^{6}$ Taiwan and Korea, transitioned from authoritarianism during the third wave of democratization, prior to this they had been governed by one party and military authoritarian regimes. Indonesia and the Philippines are democracies that for decades have been subjected to strongman rule, Thailand goes back and forth between coup d'etats and restoring democracy, Vietnam and China are authoritarian, one party regime, whereas Malaysia and Singapore are electoral authoritarian regimes. The realities of Asia's diverse regime experiences could help broaden the current understanding of the likely impacts that authoritarian legacies can have on citizens' democratic attitudes and the development of lasting democratic political cultures in the region. ${ }^{7}$

Political legacies, however, and especially authoritarian ones, are difficult to understand. For starters, there is no consensus on what counts as a legacy, what kinds of legacies there are, or how to study them. Pop-Eleches' remains the more generally accepted definition of legacy, even if it does not address how to disentangle the legacy of authoritarian regimes from the more general historical legacy. ${ }^{8}$ LaPorte and Lussier ${ }^{9}$ 
classify legacies according to their sectoral domain and the level of analysis at which they operate; yet, their work elides the question of what a legacy actually is. Cesarini and Hite ${ }^{10}$ identify two common conceptualizations, one that regards legacies as continuations of the past, and another that regards them as reactions to the past, and suggest that investigating the durability and institutional innovation of the authoritarian regime, and the mode of transition from one regime to another can help understand the relevance of the legacy of authoritarian regimes. Whitehead ${ }^{11}$, however, argues that authoritarian institutions and norms are difficult to deconstruct and so, more often than not, the political institutions built by the authoritarian leadership remain the same long after an authoritarian leader relinquishes their power. Even repeated free and fair elections may not undo bureaucracies strengthened by decades of authoritarian rule, nor avoid that new democracies inherit an important portion of their political class from previous authoritarian regimes. These realities are bound to leave a footprint on new or consolidating democracies, especially in terms of the loyalties of the countries' political elites, and especially of citizens' confidence in, and support for the institutions and processes that govern them. Thus, this article investigates the possible impacts of past authoritarian regimes on citizens' democratic attitudes in new and consolidating democracies. As such, the article aims at broadening the current understanding of what influences democratization processes and regime change in Asia, though it emphasis on citizens' attitudes and use of original, national-level survey data, represents an innovative departure from the general focus of the, mostly qualitative, mainstream literature in both fields of inquiry. ${ }^{12}$ To the extent that existing data and literature allow, the article will also investigate whether the trends emerging for Indonesia, Myanmar and Thailand differ 
or remain the same in countries like Turkey or those in the middle East and North Africa region, where the military and religion are important political and social factors, and democratic progress remains limited.

Authoritarian regimes differ in the way they constrain their citizens, which in turn is likely to lead to distinctive political beliefs and behaviour in the population. Citizens' political formative experiences in non-democratic systems are likely to impact their political attitudes regarding what form of government they see fit to run their countries, and the development of a lasting democratic political culture, once those regimes come to an end. The choice of Indonesia, Myanmar and Thailand as the case studies of this article results from their authoritarian past as well as their more recent institutional and political trajectories towards democracy. Following the 1997-1998 East Asia financial crisis, Thailand appeared to be economically fragile but politically stable as power continues to be transferred peacefully from one political group to another. Indonesia, in contrast, was just entering democratic transition and appeared on the brink of failure from the breakdown of law and order and the possibility of secession of various regions across the Indonesian archipelago. Myanmar remained one of the world's most rigidly authoritarian regimes despite the efforts of a pro-democratic opposition movement led by Nobel laureate Aung San Suu Kyi. Fast-forward 15 years, and the democratic map of Asia had changed. It included Indonesia and Myanmar, where a genuinely democratic government is starting taking shape, following Aung San Suu Kyi’s National League for Democracy victory in the 2015 general elections, but not necessarily Thailand, where military and judicial coups have repeatedly ousted democratically elected governments. Finally, it is worth mentioning that, despite its vast geographic reach, the East Asia 
region offers limited cross-national variation ${ }^{13}$ when it comes to democratic transition. In fact, only a handful ${ }^{14}$ of the 17 countries ${ }^{15}$ in the region have gone from having an authoritarian leadership to being an electoral democracy; in this regard, the choice of Indonesia, Myanmar, and Thailand as the focus countries for this article is even more compelling as it offers an opportunity to complement a relatively broad body of knowledge on the subject at hand that mainly focuses on the Philippines, South Korea, and Taiwan.

\section{Data and approach}

The primacy of democracy requires that large majorities of citizens consider democracy their preferred political regime while at the same time they reject any nondemocratic alternatives. All democracies, both new and old, can perform effectively only with support from a majority of their citizens, and their support must be consistent, stable, connected to actual political behaviour, and impervious to economic shocks. Bottom line, for democratic rule to be "the only game in town"16 , citizens must show a for-better-or worse support for democratic forms of government. Citizens who are new to democracy, or have lived all, or most of their lives under authoritarian regimes, however, may be uncertain of whether democracy offers the best way to govern their countries, and their uncertainty might ultimately impact the way in which democracy develops and strengthen in their countries. The investigation of whether the legacy of authoritarian regimes in Indonesia, Myanmar, and Thailand impact these countries' democratic transition and/or consolidation will focus on measuring citizens' support for democratic forms of government as well as their rejection of authoritarian alternatives. Support for democratic forms of government without the rejection of authoritarian ones would be 
interpreted as symptomatic of the legacy of authoritarian regimes that have governed Indonesia, Myanmar, and Thailand.

The 2011 SAIS Surveys ${ }^{17}$ and the Myanmar 2014 Civic Survey ${ }^{18}$ include several similar questions, including four questions posing radically different alternative forms of government, and asking respondents to evaluate each political system: "I'm going to describe various types of political systems and ask you what you think about each as the way of governing this country. For each one, would you say it is a very good, fairly good, fairly bad or very bad way of governing this country? R1. Having a strong leader who does not have to bother with parliament and elections; R2. Having experts, not government, make decisions according to what they think is best for the country; R3. Having the army rule; R4. Having a democratic political system.” These four questions measure support for democratic rule and rejection of three forms of authoritarian rule, which have been long practiced in Indonesia, Myanmar, and Thailand as well as the rest of East Asia. As detailed in Appendix 2 and 3 to this article, the responses to the four original questions have been operationalized in three ways; first, they were used as selfstanding variables to assess respondents' support for democratic forms of government and/or authoritarian rule; second, the responses to the four questions have been used to construct country-specific scales to measure citizens' support for democratic rule and rejection of authoritarian alternatives along a continuum ${ }^{19}$; then, the country-specific scales were used as the dependent variables in a series of binary logistic regression models to investigate the socio-demographic, cultural, economic, and political characteristics of Indonesian, Burmese, and Thai citizens who see democratic rule as the best way to govern their countries. ${ }^{20}$ 
The methodological challenge of establishing comparability in any cross-national survey is formidable. This article compared national responses to questions that are identically worded but must be translated into a number of different languages and administered in different cultural and institutional contexts. The author remains aware that standardization does not solve the problem of cross-cultural validity, and the resulting analysis take this issue under consideration by striking a balance between generalizing cross-national comparisons and contextualizing the meaning and significance of data in their political and cultural settings. The 2011 SAIS Surveys and the Myanmar 2014 Civic Survey are part of a new generation of comparative public survey projects -- such as the regional Barometer Surveys and the World Value Survey (WVS) - which increasingly cooperate with one another to standardize questions and response formats to achieve global comparability in understanding the role played by attitudes and values toward politics, governance, democracy, and political reforms.

\section{Findings}

\section{Trends for citizens' support for democratic and non-democratic forms of government}

As shown in Figure 1, data from the 2011 SAIS Surveys and the Myanmar 2014 Civic Survey reveals that, across the three countries, citizens are favorably disposed toward democratic rule, but not necessarily committed to it, which might suggest that democratic forms of government are seen/perceived "as a second-best alternative, or as a lesser evil by comparison with a plurality of undemocratic alternatives." ${ }^{21}$ In Indonesia, a total of $79 \%$ of citizens answered that "having a democratic political system" is "very good" or "fairly good" for their country. However, respondents do not universally reject "army rule", or "rule by a strong leader", or a system run by “experts". In 2011, 41\% 
endorse "having a strong leader who does not have to bother with parliament and elections", 53\% are attracted to a country run by technocrats rather than the government, and $52 \%$ state that "having the army rule" is "very good" or "fairly good". In spite of Indonesia 1998 successful democratic transition, following more than 30 years of "rule by a strong leader" (i.e. President Suharto), citizens seem still uncertain on whether a democratic political system is the best way to govern their country.

In Thailand, 79\% of Thais answered that "having a democratic political system" is "very good" or "fairly good" for their country. However, as in the case of Indonesia they too do not universally reject "army rule", "government by a strong leader", and a system run by "experts". Moreover, 62\% endorse "having a strong leader who does not have to bother with parliament and elections", $55 \%$ are attracted to a society "run by technocrats rather than the government", and $43 \%$ state that "having the army rule" is "very good" or "fairly good." This is hardly surprising for a country which has had 21 coups d'etat since 1932, and where the name of the political structure chosen to govern the country may have changed, but where the political power has remained firmly in the hands of the urban elites of Bangkok, who consistently challenge democratic institutions and keep the masses from having a meaningful participation in the country's political life. $^{22}$ 


\section{Figure 1. Citizens' support for democratic and non-democratic forms of government in Indonesia, Myanmar, and Thailand}

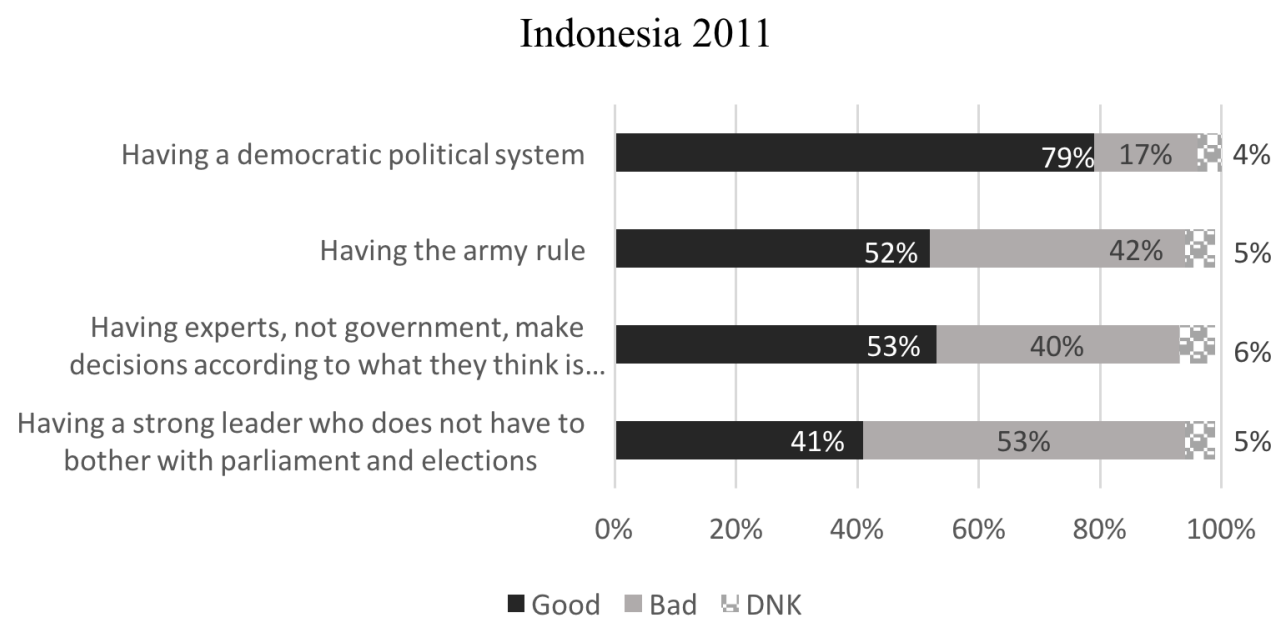

Myanmar 2014

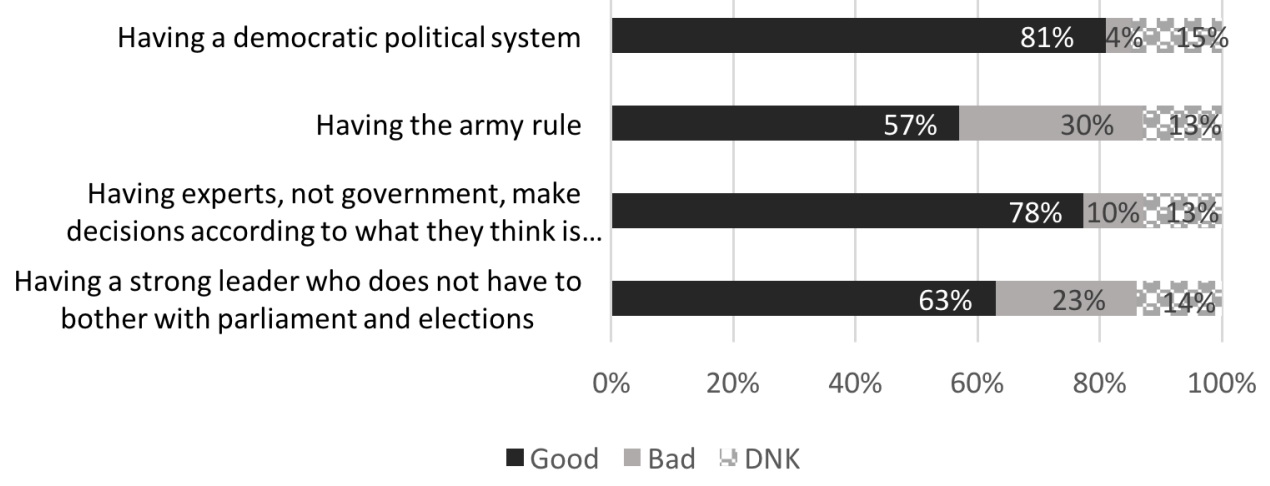

Thailand 2011

Having a democratic political system Having the army rule

Having experts, not government, make decisions according to what they think is best.. Having a strong leader who does not have to bother with parliament and elections

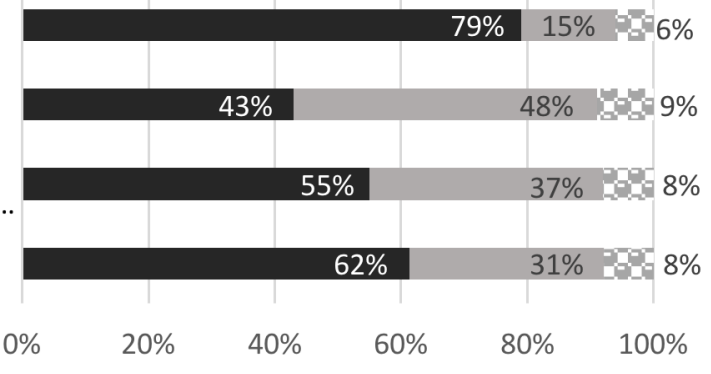

- Good Bad $=$ DNK

Source: 2011 SAIS Surveys, Indonesia and Thailand datasets; Myanmar 2014 Civic Survey 
As for Myanmar, $81 \%$ of citizens answered that "having a democratic political system" is "very good" or "fairly good" for their country. Following in the footsteps of Indonesian and Thais, Burmese too do not reject "army rule", "government by a strong leader", and a system run by experts. In 2014, $63 \%$ of Burmese fully endorse "having a strong leader who does not have to bother with parliament and elections", $78 \%$ are attracted to a society run by technocrats rather than the government, and $57 \%$ state that "having the army rule" is "very good" or "fairly good". The consistency of the findings from Myanmar with those for Indonesia and Thailand should not be dismissed in light of the excitement and expectations that the victory of Daw Aung San Suu Kyi's National League for Democracy in the November 2015 general elections has sparked both in Myanmar and abroad ${ }^{23}$, but rather seen as a cautionary tale for how citizens might feel about democratic or authoritarian rule as offering the best solutions to the problems facing their country.

Rejection of "army rule" appears to be more pronounced than rejection of the other two authoritarian alternatives in Myanmar and Thailand, thus suggesting that citizens in these countries might be rejecting the extensive involvement that the military has had/continue to have in the politics in the two countries. Military rule is basically the only form of government that the overwhelming majority of citizens in Myanmar has ever known. In fact, since General Ne Win's coup d'etat in 1962, Myanmar oscillated between direct and indirect forms of military rule whose ever-growing expansion has resulted in the military becoming the state, the weakening of civilian institutions, and significant limitations for people's participation in politics and government. ${ }^{24}$ Because of this, popular challenges to military rule have been sporadic at best: the 1988 student 
protests, the 1990 elections, the 2007 Saffron Movement, and most recently the 2015 elections. While the events of 1988 and 1990 led to a military coup, the developments since 2007 seem more promising, which might be the reason why citizens openly reject military rule as one of the forms of government best suited to govern Myanmar. As for Thailand, the reason why Thais feel that "army rule" is not the best option to govern their country might be rooted in the fact that the military has been playing "political and institutional referee" since it led the 1932 bloodless coup, which ended absolute monarchy and introduced a Western-style constitutional monarchy. ${ }^{25}$ What followed however, was not a participatory democratic system even if democratic institutions (such as an elected parliament, a judiciary, political parties, and competitive elections) were established. For decades, government in Thailand consisted of the exchange of power among competing entourages of the Thai elite, who were places in power by a faction of the military usually through a bloodless coup d'etats followed by elections held to legitimize the new government in the eye of the Thai people, once a new configuration of power had been settled in Bangkok. As a result, from 1932 to 1973, Thailand was run as a bureaucratic polity: policies were made by few officials, political life was limited to the top levels of the military and civilian bureaucracy, and a small number of families, each competing for the power and wealth needed to remain in office. Then, between 1973 and 1996 Thailand became a demi-democracy: military rule was coupled with elements of a parliamentary democracy, and the political system was gradually opened to groups other than the Bangkok elites and the military. Finally, between 2006 and 2016, Thailand experienced significant political instability marked by the Thai army declaring martial 
law and suspending the constitution, and having the National Assembly electing the army chief, General Prayut Chan-o-cha to be prime minister.

Rejection of "army rule" is slightly less pronounced in Indonesia possibly because of the institutional changes that took place after the fall of President Suharto in May 1998. The armed forces, in fact, had been central to President Suharto's New Order, with serving military officers occupying posts in the cabinet, the bureaucracy, and the legislature. President Suharto's doctrine of dual function reserved a socio-political role for the military in addition to its defense one. Its command structure distributed troops throughout the country as part of a hierarchical structure that shadowed civilian government at every level, allowing the military to regularly intervene in routine affairs of government from top to bottom on a daily basis. Finally, the military provided the coercive power that President Suharto needed to repress its critics. Many of the street protests that accompanied the 1998 regime change took a strongly anti-military tone, which made officers realize that the military's reputation as an institution had been damaged by political engagement. In response, the police forces were separated from the armed forces and given primary responsibility for maintaining domestic security. Moreover, the practice of allowing serving officers to occupy posts in the civilian bureaucracy as well as the military direct involvement in political affairs was halted. While the military devised this "new paradigm", the civilian government showed significant reluctance to intrude on certain core military prerogatives for fear of antagonizing them, and negatively impacting the country democratic transition, which ultimately resulted in limited efforts to civilianize the defense bureaucracy, reduce the military's involvement in business, especially at the local level, and, especially, dismantle 
the military's territorial system. The military is no longer a direct player in high politics in Indonesia, and yet, to a certain extent, it still retains the institutional capacity and the mindset that could allow it to intervene in the future.

Rejection of "expert rule" presents interesting cross-countries variations. It ranges from $40 \%$ for Indonesia, to $37 \%$ for Thailand, to $10 \%$ for Myanmar. The relevance and familiarity of technocrats in Asian countries is well documented and, in general, considered positive from a political point of view as with the exception of Japan's highly insulated bureaucracy, technocrats in Asia have had/have political weight only in certain areas, such as economic planning, and generally derived their relevance and authority from the country's president or prime minister. Citizens' acknowledgement of the important policy role that experts can have is not the same as "having a strong leader who does not have to bother with parliament and elections" and yet it suggests a propensity for decision-making processes that do not necessarily involve the will or participation of the people. Finally, also the trends for rejection of "rule by a strong leader" show significant cross-country variation ranging from $53 \%$ in Indonesia, to $31 \%$ in Thailand, to $23 \%$ in Myanmar. These findings suggest that the legacies of President Suharto in Indonesia, Prime Minister General Prem in Thailand, President General Ne Win and the other generals of the Burmese military junta cast long shadows over their countries' politics, and for many citizens in Myanmar, Thailand and Indonesia "rule by a strong leader" still represents an acceptable institutional alternative to a real democratic political system. $^{26}$

Finally, support for democracy is very strong across the three countries, with $81 \%$ in Myanmar, and 79\% both in Thailand and Indonesia. These findings, when compared 
with what the data has revealed regarding mass attitudes regarding "army rule", or "rule by strong leader" or by "experts", suggest that mass sentiments about which forms of government are best suited to govern these countries are inchoate and do not, in and of themselves, provide the support that might be needed to guarantee the strengthening or

the survival of democracy. ${ }^{27}$ This might be one of the reasons why Thailand remains just a step away from rolling back into authoritarianism, the prospects for a successful democratic transition remain uncertain in Myanmar, and for Indonesia trade-off between democratic success and democratic quality. ${ }^{28}$

\section{Predictors for citizens' support for democratic rule in Indonesia, Myanmar and Thailand}

For Rose, Mishler and Haerpfer democratic transition and the establishment or restructuring of democratic rule are just the "hardware of representative democracy"29 and require a congruent "software" to last and work properly. ${ }^{30}$ In this regard, there is growing recognition, in academia and among policy-makers, of the key role that citizens are playing in fostering democratization in Asia. Yet, there remain significant knowledge gaps regarding the characteristics of citizens who favor democratic rule, or how citizens orient themselves toward democracy, or how and why some commit themselves to democracy unconditionally whereas others remain attached to authoritarianism and only develop a shallow attachment to democracy. To help broaden the existing knowledge base of some of these issues, a series of binary logistic regression models have been designed to help identify the predictors for citizens' support for democratic rule in Indonesia, Myanmar and Thailand. ${ }^{31}$ The logistic regression models use as dependent variable country-specific scales that measure support for democratic forms of government and rejection of authoritarian alternatives along a continuum. ${ }^{32}$ The country-specific 
scales, presented in Figure 2, have been constructed using the responses of the four separate questions on support for democratic rule and rejection of authoritarian forms of government ${ }^{33}$ included in the 2011 SAIS Survey and the 2014 Myanmar Civic Survey.

\section{Figure 2. Scales for citizens' support for democratic and non-democratic forms of government in Indonesia, Myanmar and Thailand.}

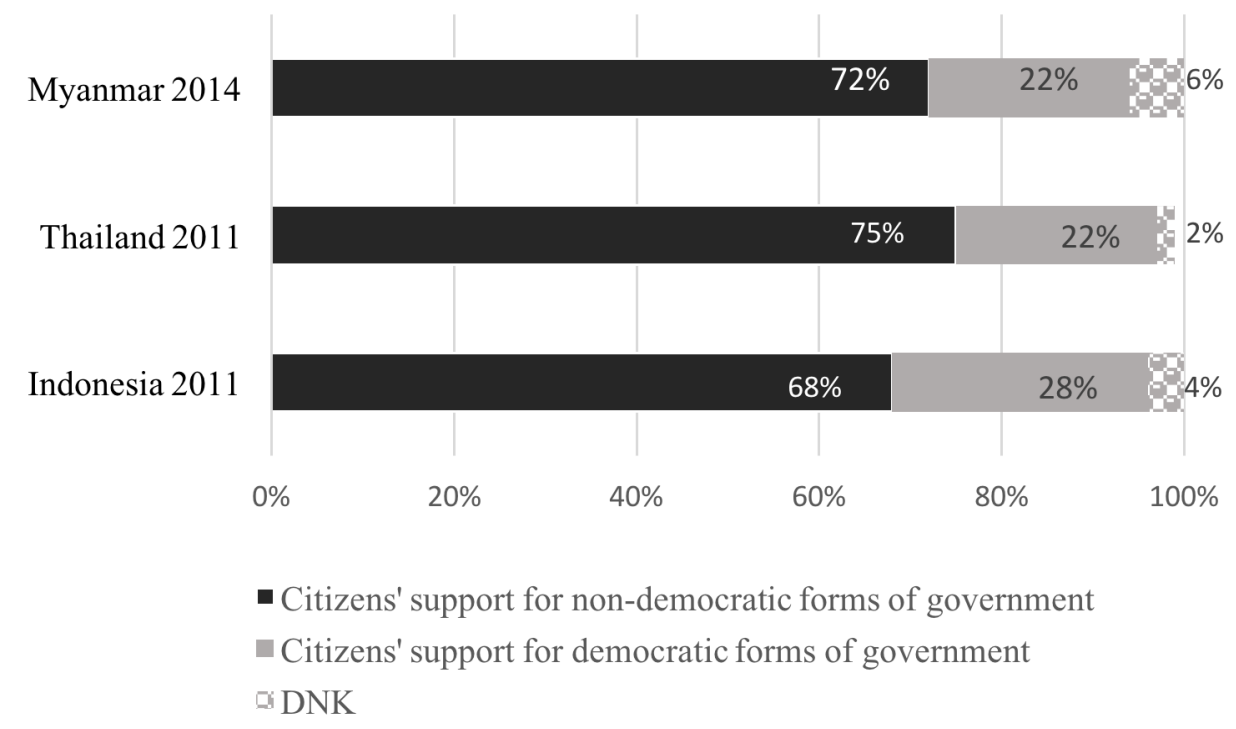

Source: 2011 SAIS Surveys and Myanmar 2014 Civic Survey

As shown in Table 1, being a resident of Jakarta makes a difference in Indonesia. Those who reside in the capital city are two times more likely to support democratic forms of government $(\operatorname{Exp}(B)=2.037)$ than Indonesians who reside in secondary cities $(\operatorname{Exp}(B)=1.4)$ or rural areas $(\operatorname{Exp}(B)=1.3) \cdot{ }^{34} \mathrm{Jakarta}$ used to be the primary locale of the anti-Suharto movement and, as these results suggest, the city's democratic clout has further strengthened, and the capital continues to be "a primate city in that it plays a vital role as the main disseminating center of social, political and economic innovation." ${ }^{35}$ Moreover, as $18 \%$ of the population lives in Jakarta and $43 \%$ in urban areas other than 
the capital city, the strong "Jakarta effect" suggests that support for democratic forms of government might not be an effect of urbanization, but solely the effect of living in the capital. Finally, this finding could be a sign of the fact that Indonesia's ambitious decentralization reform ${ }^{36}$, which transferred administrative and budgetary responsibilities to lower levels of government, has yet to show a lasting impact on Indonesia's democratic governance.

In 2011, in Indonesia, $45 \%$ of respondents were pessimistic about the country’ economic prospects whereas $56 \%$ claimed to be optimistic. The latter group seemed to be more in tune with the fact in the Spring of 2011 Indonesia was experiencing a period of sustained economic growth, which made its economy the poster story among Asian economies for that year. And yet, the positive impact of being either optimistic or pessimistic about the Indonesian economy on citizens' support for a democratic political system is very much the same (i.e. $(\operatorname{Exp}(B)=2.4$ for those who see the "economy going in the right direction", and $\operatorname{Exp}(B)=2.2$ for those who see the "economy going in the wrong direction") ${ }^{37}$. These findings suggest that while individual perception of the country's economy may be important, its impact on respondents' support for democratic form or government is limited; this finding may also suggest that democracy is not likely to rise or fall according to whether Indonesians perceive their country's economy to be growing.

Social capital is a key concept in the political realm and yet it does not have a clear, undisputed meaning, for substantive and ideological reasons. ${ }^{38}$ Bourdieu defines social capital practically as "the aggregate of the actual or potential resources which are linked to possession of a durable network of more or less institutionalized relationships of 
mutual acquaintance or recognition"39, even more tangibly, Fukuyama argues that: "social capital can be defined simply as the existence of a certain set of informal values or norms shared among members of a group that permit cooperation among them." 40 The 2011 SAIS Surveys include several questions investigating citizens' involvement/ participation in activities that help build and/or foster social capital ${ }^{41}$, such as band together to fix a damaged street, or form a neighbourhood association to pressure the government. Respondents' choice of answers that privilege collaboration signals their willingness to, and interest in building and/or foster social capital. In 2011 in Indonesia, $58 \%$ of respondents chose answers that show interest in and/or willingness to foster social capital, whereas the remaining $42 \%$ of respondents did not do so. The finding in itself is interesting because of the role academic literature attributes to building and fostering social capital in strengthening citizens' democratic attitudes ${ }^{42}$. However, the regression model reveals that citizens with an inclination to pursue activities that build/ foster social capital are only slightly more likely to support democratic forms of government than who are not so inclined (i.e. $\operatorname{Exp}(B)=1.9$ for those who engage in activities that help build and/or foster social capital, and $\operatorname{Exp}(B)=1.7$ for those who do not do so $)^{43}$, thus suggesting that, in Indonesia, citizens' interest in behaviors that would build and/or strengthen the country's social capital could be as nascent as democracy itself. 
Table 1. Indonesia 2011: Summary results for logistic regression model for citizens' support for democratic political systems.

\begin{tabular}{|c|c|c|c|c|}
\hline & B & SE & Sig & $\operatorname{Exp}(B)$ \\
\hline \multicolumn{5}{|c|}{ Social capital formation } \\
\hline Citizens' non-group response & .323 & .121 & .004 & 1.701 \\
\hline Citizens' group response & .211 & .238 & .005 & 1.984 \\
\hline \multicolumn{5}{|c|}{ Urban and rural status } \\
\hline Jakarta & .721 & .151 & .002 & 2.037 \\
\hline Other urban areas & .654 & .111 & .000 & 1.447 \\
\hline Rural areas & .756 & 134 & .012 & 1.398 \\
\hline \multicolumn{5}{|c|}{$\begin{array}{l}\text { "Do you think that, generally speaking the economy, in Indonesia today, is going in the right or } \\
\text { wrong direction?" }\end{array}$} \\
\hline Right direction & .672 & .221 & .002 & 2.410 \\
\hline Wrong direction & .514 & .119 & .001 & 2.213 \\
\hline \multicolumn{5}{|c|}{$\begin{array}{l}\text { Regression model reference category: respondents who support a democratic form of } \\
\text { government } \\
\mathrm{N}=1291 \text {; Chi Square: } 193.99 \text {; Cox and Snell } \mathrm{R}^{2}=18.1 \% \text {; Nagelkerke } \mathrm{R}^{2=} \mathbf{2 8 . 8 \%} \\
\text { * The table presents the results for the variables that turned out to be statistically significant; see } \\
\text { Appendix } 3 \text { for a full list of the variables included in the model. }\end{array}$} \\
\hline
\end{tabular}

In Myanmar, citizens emerged as cautiously optimistic about the 2015 general elections as $77 \%$ of them believed that voting could lead to improvements in the near future, whereas $10 \%$ felt that the country would not experience change, regardless of how citizens vote. As for the 2015 general elections themselves, $68 \%$ of all respondents believed that elections would be free and fair, with more optimism in the regions (i.e. $72 \%$ ) than in the states (i.e. $56 \%$ ). In addition as shown in Table 2, citizens who agreed on the November 2015 elections to be free and fair were 3.7 times more likely to support democratic institutions. ${ }^{44}$ These findings are consistent with data and experiences from around the world which show that citizens' expectations surrounding breakthrough 
political events - such as the first time holding of free and fair elections - might have a significant influence on citizens' preference for the kind of political system they want for their country. ${ }^{45}$

Public trust in various governance institutions emerged as a predictor for citizens' support for democratic rule ${ }^{46}$, even if only few respondents trust them highly. Overall, the offices of the president, the village- tract/ward administrators, and in international organizations/NGOs were viewed most favourably by the public, while the courts and the army received some of the lowest positive rating. Proximity, and thus the possibility of oversight, is likely to be the reason why Burmese trust local level institutions; in the case of the president, citizens' views might have been influenced by the fact that President Thein Sein has brought about some long overdue changes to the political and economic life of Myanmar. While interactions between the Burmese and international organizations/NGOs have been limited to humanitarian interventions, as in the case of cyclone Nargis in 2008, they have delivered tangible, positive results, which also helped carve out some space for local NGOs to operate. These findings suggest the existence of some horizontal accountability, which would need to develop further as Myanmar continues to democratize. In this regard, it is important to note that social trust itself is not a statistically significant predictor for support for democratic political systems, and that Burmese have low levels of social trust, with only $19 \%$ of all respondents agreeing that most people can be trusted, whereas and $77 \%$ of them stating that most people cannot be trusted. The lack of social trust may be a legacy of military rule, which relied on informers, and pitted neighbor against neighbor in an effort to discourage the emergence of any opposition. Democracies with low levels of social trust are prone to conflict, have 
difficulty in getting citizens to participate in politics, and to forge relationship not only across different social, ethnic, or religious groups but also across political elites. ${ }^{47}$

The 2014 Civic Survey probed citizens' satisfaction with the political and economic performance of the government (both at national and local levels) to learn about the public's views regarding the country's ongoing dual transition from state socialism to capitalism and from civil-military rule to democratic rule. ${ }^{48}$ Citizens' satisfaction with the president's decisions about the Myanmar's political and economic transitions (i.e. the "performance of the president") emerges as more relevant than their satisfaction with the performances of any other level of government; those who are, in fact, satisfied with the "performance of the president" are 3.5 times more likely to favour a democratic political system. ${ }^{49}$ The public's views on Myanmar's economic performance also emerges as a key predictor; citizens who think that "the national government is doing a good job at reviving/developing the economy" are 2.3 times more likely to support a democratic political system. ${ }^{50}$ Positive views about the country's economy could be the result of the ambitious economic liberalization program that the Government launched in 2011. Growth rates have improved, even if the economy as a whole remains among Asia's slowest-growing, and tangible benefits for the average Burmese are trickling down slowly. As a result, close to $46 \%$ of respondents say that they have experienced no change in economic conditions, whereas $32 \%$ see current economic conditions as better than before. Finally, respondents who think that "generally speaking, the economy in Myanmar today is going in the right direction" are 2.5 times more likely to support a democratic political system ${ }^{51}$, and Burmese seems to be especially pleased in terms of political liberalization, and the improvement of the country's infrastructure. 
These results suggest that citizens' support for democratic rule might be linked to its ability to deliver certain desirable goods, which after 50-plus years of military rule characterized by economic decline and increasing poverty, is a reasonable expectation to have.

Table 2. Myanmar 2014: Summary results for logistic regression model for citizens' support for democratic forms of government.

\begin{tabular}{|c|c|c|c|c|c|}
\hline & & B & SE & Sig & $\operatorname{Exp}(B)$ \\
\hline \multicolumn{6}{|c|}{ "November 2015 elections will be free and fair" } \\
\hline \multicolumn{2}{|c|}{ Agree } & 1.333 & .121 & .000 & 3.791 \\
\hline \multicolumn{2}{|l|}{ Disagree } & 1.291 & .238 & .000 & 3.384 \\
\hline \multicolumn{6}{|c|}{ Citizens' trust in national and local level institutions } \\
\hline & Trust in the President & 1.721 & .155 & .002 & 2.037 \\
\hline & $\begin{array}{l}\text { Trust in the village tract/ward } \\
\text { administrators }\end{array}$ & 1.564 & .115 & .000 & 1.947 \\
\hline & Trust in the township administrator & .345 & .213 & .001 & 1.544 \\
\hline & Trust in the state/region Hluttaw & .234 & .243 & .017 & 1.238 \\
\hline & Trust in international organizations/NGOs & .345 & .311 & .012 & 1.792 \\
\hline \multicolumn{6}{|c|}{ Satisfaction with the government's performance at national and local level } \\
\hline & Satisfied with the President & 1.876 & .221 & .000 & 3.527 \\
\hline & $\begin{array}{l}\text { Satisfied with village tract/ward } \\
\text { administrators }\end{array}$ & .256 & .133 & .019 & 2.291 \\
\hline & Satisfied with the township administrator & .654 & .174 & .004 & 1.945 \\
\hline & Satisfied with the state/region Hluttaw & .543 & .155 & .001 & 1.634 \\
\hline \multicolumn{6}{|c|}{ Satisfaction with the national government's performance in various sectors of the economy } \\
\hline & Education & .342 & .190 & .009 & 1.707 \\
\hline & Health & .331 & .263 & .002 & 1.593 \\
\hline & Reviving/developing the economy & .467 & .111 & .000 & 2.338 \\
\hline \multicolumn{6}{|c|}{$\begin{array}{l}\text { "Do you think that, generally speaking the economy in Myanmar today is going in the right or } \\
\text { wrong direction?" }\end{array}$} \\
\hline & Right direction & .672 & .221 & .002 & 2.510 \\
\hline & Wrong direction & .514 & .119 & .001 & 1.213 \\
\hline
\end{tabular}


Regression model reference category: respondents who support a democratic form of government

$N=3000$; Chi Square: 163.21; Cox and Snell $R^{2=} 14.3 \%$; Nagelkerke $R^{2=} \mathbf{2 9 . 7 \%}$

* The table presents the results for the variables that turned out to be statistically significant; see Appendix 3 for a full list of the variables included in the model.

In Thailand, urban and rural status, attitudes towards elections, and participation in non-electoral activities are the most relevant predictors for citizens' support for democratic forms of government. Elections are the most decisive means through which citizens take part in their country's political life; elections are a blunt but powerful instrument of control over the government which does not requiring much initiative. In Thailand, elections are a regular feature of politics even though they may not fulfill entirely the functions laid out in democratic theory. Elections have, in fact, been held to legitimize new governments, or new institutional political configurations, after most of the 21 coups d'etat that have taken place in Thailand since 1932. Table 3 shows that citizens who consider elections an "opportunity for patronage" are 5 times less likely to support democratic forms of government, whereas those who see elections as "an opportunity for democratic participation" are 1.3 times more likely to support a democratic political system ${ }^{52}$, which suggest the existence of a disconnect between democracy in principle (i.e. elections are important) and democracy in practice (i.e. who elections are relevant for).

Non-electoral participation (NEP) provides a structured framework for a continuous dialogue between the electorate and their representatives. There are many kinds of activities citizens can perform to influence the government. Regardless of whether people write letters, sign petitions, or attend an election rally, participation 
beyond voting on election-day is instrumental to legitimize and strengthen democracy. NEP is a system of checks and balances that allows citizens to hold political leaders accountable while simultaneously providing them with the information necessary to understand what citizens may be thinking between elections. The SAIS 2011 Surveys asked Thais if they "have done", "might do", or "would never do" any of the following: "write a letter to a newspaper", "sign a petition", "attend a lawful demonstration", "participate in any event held by a political party", and/or "participate in an electoral meeting or rally." Figure 3 offers a snapshot of the responses to these questions, organized into an index and reveal that citizens' levels of engagement in NEP activities differ significantly depending on whether respondents reside in Bangkok or in the rest of the country, especially for "no" or "low" levels of engagement in NEP. In fact, the share of respondents who do not engage in NEP activities across Thailand is more than twice as large as that of those who live in Bangkok (i.e. $62 \%$ vs. $28 \%$ ), whereas the share of respondents who live in Bangkok and have a "low" level of engagement in NEP is four times larger than that of respondents who live elsewhere in Thailand (i.e. $54 \%$ vs $13 \%$ ) as shown in Figure 3. On the one hand, these findings confirm the political divide that exists between Bangkok and Thailand, and which has been strengthened by the volatile political climate that developed in Thailand, between 2006 and 2011; on the other, the large share of citizens that across Thailand have limited engagement in NEP signals limited horizontal accountability, which creates an additional burden to the fragile state of Thai democracy. Thus, it is not surprising that the results of the regression analysis show that Thais with "no NEP" are $60 \%$ less likely to favor democratic forms of government, 
whereas those with "low NEP" and "medium to high NEP" are respectively $40 \%$ and $20 \%$ less likely to do so. ${ }^{53}$

\section{Figure 3. Non-electoral participation in Thailand and Bangkok in 2011}

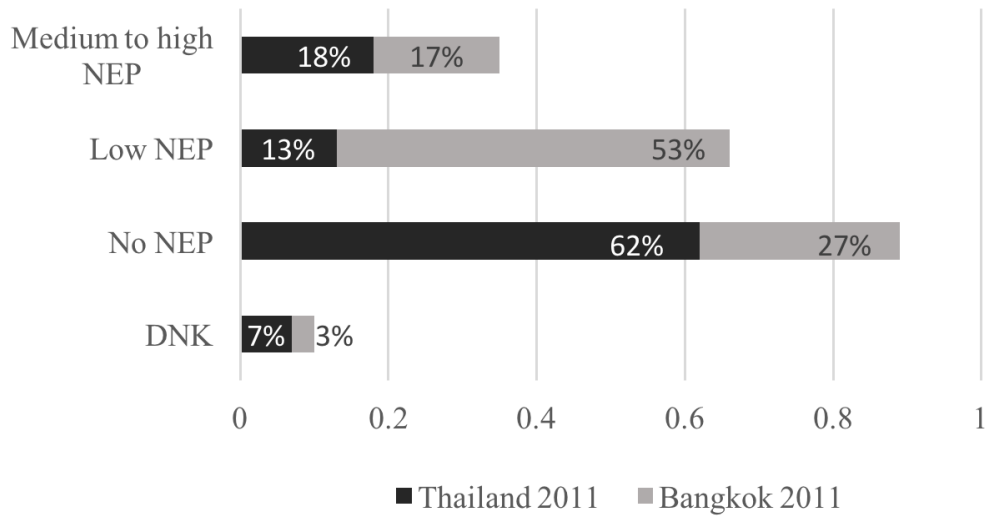

Source: 2011 SAIS Surveys, Thailand dataset.

As for urban and rural status, those who reside in Bangkok are $70 \%$ less likely to support a democratic political system, whereas citizens who reside in secondary urban centers or the rural areas are respectively $40 \%$ and $20 \%$ less likely to support a democratic political system. ${ }^{54}$ These results suggest that support for a democratic political system is more easily found away from Bangkok, which is an encouraging finding because $62 \%$ of the population resides in rural Thailand. However, these data also confirm that Thailand's capital remains a stronghold of those elites who do not advocate for a more democratic Thailand. Twenty-one different constitutions may have officially sanction democratic institutions but did not succeed in transferring power needed to determine the political agenda from the military and the elites to the people; yet, popular pressures have not been sufficiently mature to force this kind of change. For a very long 
time, the Bangkok elites has ruled the country to their benefit with the help of the military, the technocrats, and the backing of the monarchy. Thai people remain at the heart of Thailand democratic future. Yet, it is unclear whether their democratic support is strong enough to keep democracy safe and consolidate. Elected but unaccountable power coupled with absolute authority have not led Thailand to happy democratic endings as the experiences in the 1960s, 1970s, and early 1990s have demonstrated.

Table 3. Thailand 2011. Summary results for logistic regression model for citizens' support for democratic forms of government

\begin{tabular}{|c|c|c|c|c|}
\hline & B & SE & Sig & $\operatorname{Exp}(B)$ \\
\hline \multicolumn{5}{|l|}{ Attitudes towards elections } \\
\hline Elections are a waste of time & .956 & .398 & .016 & 2.602 \\
\hline Elections are an exercise in patronage & .964 & .264 & .000 & 2.621 \\
\hline Elections are an opportunity for democratic participation & .865 & .195 & .000 & 2.675 \\
\hline \multicolumn{5}{|l|}{ Non-electoral participation } \\
\hline No engagement in NEP activities & -1.374 & .398 & .041 & .374 \\
\hline Low levels of engagement in NEP activities & -1.395 & .264 & .043 & .595 \\
\hline Medium to high levels of engagement in NEP activities & -1.259 & .216 & .045 & .659 \\
\hline \multicolumn{5}{|l|}{ Urban and rural status } \\
\hline Capital city & -.987 & .233 & .001 & .301 \\
\hline Urban areas other than the capital city & -.764 & .198 & .003 & .603 \\
\hline Rural areas & -.469 & .211 & .007 & .798 \\
\hline \multicolumn{5}{|c|}{$\begin{array}{l}\text { Regression model reference category: citizens' support for a democratic form of government } \\
N=900 \text {; Chi Square: } 47.021 \text {; Cox and Snell } R^{2}=12.1 \% \text {; Nagelkerke } R^{2}=22.7 \% \\
* \text { The table presents the results for the variables that turned out to be statistically significant; see } \\
\text { the Appendix } 3 \text { for a full list of the variables included in the model. }\end{array}$} \\
\hline
\end{tabular}


Shadows of autocracy beyond Asia: evidence from Turkey, the middle East and North Africa.

How do the patterns described in the previous sections differ or remain the same in countries in the middle East and North Africa, where the military and religion are important political and social factors just like in Indonesia, Myanmar and Thailand?

Data from the WVS and the Arab Barometer surveys (ABS) suggest that citizens in the middle East, North Africa, and in Turkey are favorably disposed towards democratic rule. The 2006 ABS shows that 96 percent of respondents in Morocco, 93 percent in Jordan and Kuwait, 88 percent in Palestine, 81 percent in Algeria, agree that having a democratic political system would be either "very good" or "good" for their country. ${ }^{55}$ Furthermore, data from the 2012 ABS show that 70 percent of respondents in Tunisia, 73 percent in Yemen, and 85 percent in Lebanon also agree that a democratic political system would beneficial for their country. ${ }^{56}$ Finally, the WVS shows that, on average, 84 percent of respondents in Turkey favored democratic rule between 2000 and $2012 .^{57}$ These findings are consistent with what discussed earlier in the article for Indonesia, Myanmar and Thailand, and yet they might seem anomalous in a region where citizens have and continue to experience little or no democracy, and for which scholars "have long lamented that political systems have not been opened up to all citizens, and that political participation is less advanced in the Arab world than in other developing regions." 58

Despite such overwhelming support for democratic rule, "rule by a strong leader" is not universally rejected. Across Algeria, Jordan, Kuwait, Morocco, and Palestine, an average 15 to 18 percent of all respondents endorse "rule by a strong man",59, whereas close to 20 percent of respondents do so in Lebanon, Tunisia and Yemen. ${ }^{60}$ Finally, 
between 2000 and 2012, 54 percent of respondents agreed that that it would be "good" or "very good" for Turkey to "have a strong leader who does not bother with parliament and elections. ${ }^{" 61}$ This apparent contradiction is also consistent with what seen in Indonesia, Myanmar and Thailand where mass sentiments about which forms of government are best suited to govern those countries are inchoate and as such do not provide the support that democratic consolidation might need. In the case of middle Eastern and North African countries, it is also possible that contradictory attitudes reflect citizens' concerns that democratic rule could bring political instability or be harmful to vulnerable groups even if it would be beneficial for the country overall, and that a strong leader might be able to usher democratic change in a non-politically disruptive way. This might be the reason why the more significant support for "rule by a strong leader" emerges among respondents in Jordan, Morocco, and Turkey, where monarchs and presidents have been projecting an image of custodians of political order and continuity while not necessarily being accountable to their subjects or the electorate, ${ }^{62}$ and in Lebanon and Yemen, where relatively weak institutions are divided along sectarian lines and citizens might be concern that a fully-fledged democratic political system could inflame sectarian conflict and social unrest. ${ }^{63}$

In Algeria, Kuwait, Jordan, Morocco, Palestine citizens who are male, older, better educated, and interested in politics are more likely to favor democratic rule. Moreover, those who think that democratic reforms should be implemented gradually, identify authoritarianism as an issue of relevance or likely to affect democratic progress, and believe that citizens have the ability to influence government activities and policies are also more likely to support a democratic political system. Citizens' assertiveness of 
political efficacy is interesting in light of the fact that, in practice, people across these countries do not necessarily enjoy many political and personal freedoms.

Lack of public trust in the government and government institutions in general is also a predictor for citizens' support for democratic rule in Lebanon, Tunisia, and Yemen ${ }^{64}$ Turkey is the exception to this finding as both confidence in the military, the police, and the legal system are predictors for supporting a democratic political system. As in the case of Myanmar, not only did the military play a critical role in establishing the Turkish Republic, but also its involvement in political affairs is sanctioned by the Turkish constitution. As such, the military is implicitly "protected from the scrutiny, and public criticism that apply to all other sectors of society, and placed it virtually above the state ${ }^{\prime 65}$, and its frequent interventions to restrict political freedoms and influence the electorate are often justified as needed actions to ensure the survival of democracy. ${ }^{66}$

Just about only one third of all respondents, across the nine countries, believe that their governments are doing a good job at fighting inequality and unemployment; this could help explain why citizens identify the country's most pressing problem as something economic, and those dissatisfied with their governments' economic performance are more likely to favor a democratic political system. Moreover, about 50 percent of respondents in Algeria, Kuwait, Jordan, Morocco, Palestine and Tunisia define democracy in economic terms rather than in terms of political rights and freedoms ${ }^{67}$, thus suggesting that citizens' support for democracy might be conditional to the economic performance that the government could provide. This finding is consistent with what seen in Myanmar, where citizens' support for a democratic political system seemed to be linked to its the ability of to deliver certain economic goods, and yet different from what 
seen for Indonesia and Thailand, where economic considerations do not play any role in citizens' support for democratic rule.

Assertions that Islam is antithetic to democratic rule have been and continue to be used to explain the slow progress of democracy and the persistence of authoritarianism in the Arab world. ${ }^{68}$ Some scholars contend that Islam and democracy are inherently incompatible because Islam recognizes no division between church and state and emphasizes the community over the individual. ${ }^{69}$ Others argue that Islamic law and doctrine are fundamentally illiberal and hence create an environment within which democracy cannot flourish. ${ }^{70}$ Finally, there are also claims that Islam fosters antidemocratic attitudes as it does not advocate a commitment to political freedom and promotes the acceptance of the political status quo rather than fostering political competition typical of a democratic political system. ${ }^{71}$ ABS data collected between 2006 and 2012 show that, an average 85 percent of respondents across the nine countries of interest believe that democracy, despite its drawbacks, is the best political system regardless of whether respondents see themselves as more or less observant religious Muslims $^{72}$, thus suggesting that Islamic orientations have not a meaningful impact on citizens' views about democracy. Moreover, regression analysis shows that personal religiosity is not related to citizens' preference for a particular political system to a statistically significant degree. This is consistent with what the SAIS Surveys data show for Indonesia, where personal religiosity did not lead respondents to be less supportive of democratic rule or favor a political system that incorporates an Islamic dimension. Thus, contrary to the predominant existing qualitative narrative on the incompatibility between 
Islam and democracy, citizens' religious orientations do not seem to be able to explain the persistence of authoritarianism in the Arab world.

Citizens, however, seem to be divided on whether Islam should play an important political role. In 2006, in Algeria, Kuwait, Jordan, Morocco and Palestine, 56 percent of all respondents agree with the statement that men of religion should have influence over government decisions, 44 percent disagree, indicating that they believe Islam should not have an important political role. ${ }^{73}$ In 2012, trends for Lebanon, Tunisia and Yemen show consistency with those of other middle Eastern and North African countries, although with modest variations ${ }^{74}$, as well as that either favoring secular democracy or a political system that is both democratic and gives an important role to Islam does not have any statistically significance vis a vis citizens' preference for democratic rule. These findings are consistent with what the data from SAIS Surveys revealed for Indonesia, and reiterate the lack of incompatibility between Islam and democracy.

This brief comparative overview shows that people in the Arab world express support for democratic rule as much as people in Indonesia, Myanmar and Thailand, or anywhere else in the world. As in Southeast Asian countries, favouring a democratic political system in the Arab world does not necessarily translate in a universal rejection of less democratic forms of government, thus suggesting that respondents might be expressing satisfaction with the political status quo rather than with the democratic political system at work in their countries, and that they too might be lacking a "for better or worse" commitment to democracy. As in the case of Indonesia, Myanmar and Thailand, available data suggest the absence of any universal trends among countries in the middle East and North Africa for factors that help explaining citizens' support for 
democratic rule, and point to the lack of many of the political strengths and civic habits that form a political culture needed for democracy to flourish and consolidate. Finally, consistent with what seen in Indonesia, citizens' attitudes and values pertaining to Islam do not play a role in their support or rejection of democratic rule, which re-iterates the compatibility between Islam and democracy and the fact that Islam is not the reason why authoritarianism persists in the Arab world.

\section{Conclusions}

The end of authoritarianism, following the end of WWII, opened the door to democracy for some countries in Asia; and yet, it offered no guaranteed for democracy to flourish or effectively counter the resilience of authoritarianism in the region. ${ }^{75}$ The analyses of the data from the 2011 SAIS Surveys and the Myanmar 2014 Civic Survey revealed that citizens in Indonesia, Myanmar and Thailand lack a "for-better-or-worse" commitment to democracy as they state their support for democratic forms of government without rejecting authoritarian alternatives. There are, in fact, 2.4 Indonesians who support non-democratic forms of government for every one that supports democratic rule, whereas the ratio for Myanmar and Thailand is 3.4 to 1 and 3.2 to 1 respectively, thus suggesting that the legacy of authoritarian regimes looms large in the democratic future of these countries. Moreover, there seem to be no universal trend among the countries but rather countries' specific combinations of factors that explain citizens' support for democratic rule in Indonesia, Myanmar and Thailand. In Indonesia, it has to do with where citizens reside, whether they engage in activities which build and/or foster social capital, and their overall views of the economy. In Thailand, it is, again, where respondents live, in addition to citizens' attitudes and behavior regarding elections, and 
participation in the country's political life between elections. In Myanmar, it is a mix of mass sentiments ranging from trust in, to satisfaction with governing institutions at national and local levels, and democratic processes like elections, and citizens' overall views of the economy, as in the case of Indonesia. All in all, these findings reveal that even those citizens who wholeheartedly support democratic rule appear to lack many of the political strengths and underlying civic habits that the literature see as needed for the development of a lasting democratic political culture. Finally, a brief comparative overview show consistency between several of the trends emerged for Indonesia, Myanmar and Thailand and those in middle Eastern and North African countries. Specifically, large majorities of citizens in the Arab world favor democratic rule, and yet they do not universally reject non-democratic forms of government. Universal trends for factors that help explaining citizens' support for democratic rule among countries in the middle East and North Africa are also missing as well as many of the political and civic habits that form a political culture needed for democracy to flourish and consolidate.

Finally, consistent with what seen in Indonesia, citizens' attitudes and values pertaining to Islam do not play a role in their support or rejection of democratic rule, which re-iterates the compatibility between Islam and democracy and the fact that Islam is not the reason why authoritarianism persists in the Arab world.

Socialization theory ${ }^{76}$ might help explaining why citizens remain attached to the political values of authoritarianism after its demise, and why it might difficult for citizens to re-orient themselves toward the values of liberalism and pluralism typical of democratic regimes. The more strongly the values and institutions of the pre-democratic period have been socialized, the more cautious or ambivalent they are to embrace 
democracy as the preferred form of government for their countries, and to support it to guarantee its survival. The legacy of Suharto's authoritarian regime manifests itself in Indonesia being both a success story, one which has institutionalized democratic freedoms and rolled back the military as well as a story of low democratic quality, corruption, and capture of democratic institutions by President Suharto's era elites. Both accounts are correct as "the success of Indonesia's democracy and its poor quality are two sides of the same coin. It was precisely by achieving a low-quality outcome that Indonesian democratization succeeded. Elites and potentially disruptive political forces such as the military were not excluded from Indonesia's new democracy. Instead, they were all given a piece of the (democracy) pie, reducing their incentive to resist and challenge the system from the outside. The price of this approach was that the potential spoilers were empowered to undermine the quality of Indonesian democracy from within and, more importantly, patronage and corruption became means by which they were brought into the system." 77 Yet, in a democratic system where everyone still has a stake, the dangers of erosion from within are real, and bedevil democratic consolidation. In Myanmar, the legacy of authoritarianism appears to be embedded in the country's political and civic culture, and manifests itself in lack of underlying liberal values that are critical to a "for-better-or-for-worse" commitment to democracy. Without widespread support, current appeal for democracy may fade quickly leaving Myanmar's democratic transition vulnerable to breakdown; the success of the ongoing transition hinges on the former political opposition's ability to strengthen the relevance of reformers without antagonizing the military, who still enjoy significant constitutional guarantees and power. The impact of Thailand's authoritarian past appears to cast a long shadow on the 
country's democratic consolidation. The establishment of a Western-style constitutional monarchy in 1932 did not necessarily give Thailand a participatory democratic system even if democratic institutions, such as an elected parliament, a judiciary, political parties, and competitive elections were established. To date, and with few exception, changes in governments have been nothing more than an exchange of power among competing entourages of the Thai elite helped by a faction of the military, usually through bloodless military coup d'etas, or more recently through votes of no confidence in Parliament. Once a new configuration of power has been settled in Bangkok, elections are held to legitimize the new government in the eyes of the Thai people.

In Indonesia, Myanmar, and Thailand shallow popular support for democratic forms of government increases the vulnerability of democracy and make it susceptible to the breakdown of law and order, or the advent of a charismatic figure who could exploit the strength of lingering authoritarian values for political purposes. The legacy of authoritarianism hangs over Indonesia, Myanmar and Thailand. Yet, the fact that these countries have democratic institutions and democratically elected governments represents an improvement over the authoritarian political systems they had in the past. As new democracies, they display few of the institutional strengths and underlying habits of participation for which scholars and policy makers had hoped. Accountability remains a problem, and non-electoral participation seems capable of filling the participatory void characteristic of incomplete democracies. Much of the public software of democracy remains a work in progress, which places a heavy burden on national leaders to foster trust among themselves and a consensus on democratic practice across their societies, and consistently stand in favor of popular sovereignty if democracy is to survive. Because 
liberal democracy requires positive and simultaneous achievements on each of these dimensions, it is, and probably always will be, a work in progress. The difficulty involved in approaching all of these goals simultaneously is one reason why democracy remained an abnormal form of government until the second half of the 20th century, and possibly why it made limited progress, and continues to suffer in Indonesia, Myanmar, and Thailand.

\section{Notes on contributor}

Giovanna Maria Dora Dore holds a PhD in Comparative Politics and Asian Studies from Johns Hopkins University-SAIS (Washington D.C., USA), and is a Professorial Lecturer at the Johns Hopkins University-Zanvyl Krieger School or Art and Science. Dr Dore's comparative politics research focuses on democratic development in Asian countries, and the rise of authoritarianism in western liberal democracies.

\section{Acknowledgements}

I would like to express my gratitude to Prinat Apirat, Bjorn Dressel, Karl D. Jackson, Kim Ninh, Filipa Alves Raimundo, Jose' Pereira, and David I. Steinberg for their valuable comments and feedback to this article.

\footnotetext{
${ }^{1}$ Freedom House. 2012 Freedom in the World Survey. www.Freedomhouse.org

${ }^{2}$ Hsin-Huang Michael Hsiao (Ed). 2014. Democracy or Alternative Political Systems in Asia. London, UK and New York, NY: Routledge.

Yin-wah Chu, Siu-lun Wong (Eds). 2010. East Asia’s New Democracies: Deepening, Reversal, Non-liberal Alternatives. New York, NY: Routledge.

Hicken, Allen. 2008. Developing Democracies in Southeast Asia. Stanford, CA: Stanford University Press. Larry Diamond, Marc F. Plattner, Yun-han Chu (Eds). 2013. Democracy in East Asia: A New Century. Baltimore: MD: Johns Hopkins University Press.

Larry Diamond, Juan J. Linz, and Seymour Martin Lipset. (Eds). 1989. Democracy in Developing Countries Asia Volume Three. Boulder, CO: Lynne Rienner.

${ }^{3}$ Adam Przeworski and Fernando Limongi. 1993. "Political Regimes and Economic Growth." The Journal of Economic Perspectives. Vol. 7(3): 51-69.

Kevin Hewison, Richard Robison, and Garry Rodan (Eds). 1993. Southeast Asia in the 1990s: Authoritarianism, Democracy, and Capitalism. Singapore: Allen and Unwin.

${ }^{4}$ R. J. Dalton and N.H. Ong. (2006). "Authoritarian Orientations and Democratic Regime Preferences: A test of the Asian Values Hypothesis.” In R. J. Dalton \& D. C. Shin (Eds). 2006. Citizens, Democracy, and Markets around the Pacific Rim. York, NY: Oxford University Press.
} 
Mark R. Thompson. 2004. "Pacific Asia after Asian Values: Authoritarianism, Democracy, and Good Governance.” Third World Quarterly. Vol. 25(6): 1079-1095.

Fareed Zakaria 1994. "Culture Is Destiny. A Conversation with Lee Kuan Yew.” Foreign Affairs. Vol. 73(2):109-26

Huntington, Samuel P. 1993. “The Clash of Civilizations?” Foreign Affairs. Vol. 72(3): 22-49.

Thompson, Mark. 2004. Democratic Revolutions. Asia and Eastern Europe. London, UK: Routledge.

Lucien Pye. 1974. Southeast Asia's political systems. New Jersey: Prentice-Hall.

Samuel P. Huntington. 1968. Political Order in Changing Societies. New Haven: Yale University Press.

${ }^{5}$ Pei, Minxin. 1994. “The Puzzle of East Asia Exceptionalism”. Journal of Democracy. Vol. 5: 90-103.

${ }^{6}$ Hsin-Huang Michael Hsiao (Ed). 2014. Democracy or Alternative Political Systems in Asia. London, UK and New York, NY: Routledge.

Chang, Yu-tzung, Yun-han Chu, and Chong-Min Park. 2007. “Authoritarian Nostalgia in Asia.” Journal of Democracy. Vol. 18(3): 66-80.

Chang, Yu-tzung, Yun-han Chu, and Min-hua Huang. 2006. "The Uneven Growth of Democratic Legitimacy in East Asia.” International Journal of Public Opinion Research. Vol. 18(2): 246-255.

${ }^{7}$ Dan Slater. 2006. "The Architecture of Authoritarianism: Southeast Asia and the Regeneration of Democratization Theory." Taiwan Journal of Democracy. Vol. 2(2): 1-22.

Donald K. Emmerson. 1995. "Region and Recalcitrance: Rethinking Democracy Through Southeast Asia." Pacific Review. Vol. 8(2): 225-243.

Stephan Haggard and Richard Kaufman. 1995. The Political Economy of Democratic Transitions. Princeton, NJ: Princeton University Press.

${ }^{8}$ G. Pop-Eleches. 2007. "Historical Legacies and post-communist regime change." Journal of Politics. Vol. 69(4): 908-926.

${ }^{9}$ Jody LaPorte and Danielle N. Lussier. 2011. What Is the Leninist Legacy? Assessing Twenty Years of Scholarship. Slavic Review. Vol. 70(3): 637-654

${ }^{10}$ Cesarini, P. \& Hite, K. 2004. "Introducing the concept of authoritarian legacies", in Hite K. and Cesarini P. (Eds.) Authoritarian Legacies and Democracy in Latin America and Southern Europe. Notre Dame: University of Notre Dame Press.

${ }^{11}$ Laurence Whitehead. 2013. "Personalist Leadership Styles and Legacies: A Comparative Survey of East and Southeast Asian Nations". In Hsin-Huang Michael Hsiao (Ed). Democracy or Alternative Political Systems in Asia: After the Strongmen. London: Routledge Contemporary Asia Series.

${ }^{12}$ Hsin-Houng Michael Hsiao (Ed). 2014. Democracy or Alternative Political Systems in Asia. After the Strongman. New York, NY: Routledge.

Dan Slater. 2006. "The Architecture of Authoritarianism: Southeast Asia and the Regeneration of Democratization Theory." Taiwan Journal of Democracy. Vol. 2(2): 1-22.

Richard Rose and William Mishler. 2002. "Comparing Regime Support in Non-democratic and Democratic Countries. Democratization. Vol. 9(2): 1-20.

William Case. 1996. "Can the 'Halfway House' Stand? Semi-democracy and Elite Theory in Three Southeast Asian Countries.” Comparative Politics. Vol. 28(July): 437-64.

${ }^{13}$ Cross-national research is the technique of analysing an event or process that takes place within a country, while comparing the way that event or process takes place across different countries.

${ }^{14}$ Indonesia, Myanmar, the Philippines, South Korea, Taiwan, and Thailand.

${ }^{15}$ The countries that are included in the definition of East Asia vary depending on the geographic classification that is chosen. For the purpose of this article, the list of countries is based on the list of the 
countries the International Monetary Fund uses, and include: Cambodia, China, Brunei, Indonesia, Japan, Lao PDR, Malaysia, Mongolia, Myanmar, North Korea, Philippines, Singapore, South Korea, Taiwan, Thailand, Timor Leste, and Vietnam.

${ }^{16}$ Juan J. Linz and Alfred Stepan. 1996. Problems of Democratic Transition and Consolidation. Baltimore, MD: Johns Hopkins University Press.

${ }^{17}$ The "2011 SAIS Surveys" are national-level opinion surveys, which targeted Indonesia, Korea, the Philippines, and Thailand, with a total sampling size of 4,000 individuals, and a questionnaire of 153 questions. AC Nielsen implemented the surveys across the four countries, and the field-work was divided in two phases: the pre-test phase, and the implementation phase. The 2011 survey was pre-tested in each country in January 2011, through a limited number of pre-test interviews; the implementation phase took place between February and June 2011, with interviews conducted face to face at national and capital-level, with each interview lasting approximately 1.5 hours. See also Appendix 1. Description of the datasets used.

${ }^{18}$ The "Myanmar 2014: civic knowledge and values in a changing society" is the first ever national level survey done for Myanmar, with a total sampling of 3,000 individual. Seven states-Kachin, Kayah, Kayin, Chin, Mon, Rakhine, and Shan - were over-sampled to ensure that their sub-samples were large enough to be analysed. The Myanmar 2014 Civic Survey was conducted between May and June 2014 across all fourteen states and regions, used a questionnaire with 95 questions and face-to-face interviews, which lasted approximately one hour. See also "Appendix 1. Description of the datasets used".

${ }^{19}$ See "Appendix 2. Description of dependent variable operationalization".

${ }^{20}$ See Table 1 in the article for the results of the binary logistic regression model for Indonesia. Also, see "Appendix 3. Description of the binary logistic regression models" for a complete list of the variables that have been included in the model.

${ }^{21}$ Rose Richard, William Mishler, Christian Haerpfer. 1998. Democracy and Its Alternatives: Understanding Post-Communist Societies. Baltimore: Johns Hopkins University Press.

${ }^{22}$ Thitinan Pongsudhirak. 2013. "Thailand's Uneasy Passage”, in Larry Diamond, Marc F. Plattner and Yun-han Chu (Eds). 2013. Democracy in East Asia: A New Century. Baltimore, MD: Johns Hopkins University Press.

${ }^{23} \mathrm{http} / / / \mathrm{www} \cdot$ bbc.com/news/world-asia-33547036

${ }^{24}$ David I. Steinberg. 2015. "The Persistence of the Military Dominance”, in Steinberg David I. (Ed.) Myanmar. The Dynamics if an Evolving Polity. Boulder, CO and London UK: Lynne Rienner.

Lee Jones. 2014. "Explaining Myanmar's Regime Transition: the Periphery is Central." Democratization. Vol. 21(5): 2-23.

Adam P. Macdonald. 2013. "From Military Rule to Electoral Authoritarianism: The Reconfiguration of Power in Myanmar and its Future." Asian Affairs: An American Review. Vol. 40(1): 20-36.

Robert H. Taylor. 2012. "Myanmar: From Army Rule to Constitutional Rule?" Asian Affairs. Vol. 48(11): 221-236.

Morten B. Pedersen. 2011. "The Politics of Burma's Democratic Transition.” Critical Asian Studies. Vol. 43(1): 49-68.

${ }^{25}$ Prinat Apirat. 2014. "From Subjects to Citizens: Democratic Consolidation in Thailand between 2000 and 2011." In Dore Giovanna Maria Dora, Jae H. Ku, and Karl D. Jackson. 2014. Incomplete Democracies in the Asia-Pacific. Evidence from Indonesia, Korea, the Philippines and Thailand. London, UK: Palgrave Macmillan.

${ }^{26}$ Dan Slater. 2010. Ordering Power: Contentious Politics and Authoritarian Leviathans in Southeast Asia. Cambridge, UK: Cambridge University Press.

William Case. 2002. Politics in Southeast Asia: Democracy or Less. London, UK: Curzon.

Barbara Geddes. 1999. "Authoritarian Breakdowns: Empirical Tes of a Game Theoretical Argument." Paper presented at the annual meetings of the American Political Science Association. Atlanta, 1999. Also, 
"What to We Know about Democratizations after Twenty Years?" Annual Review of Political Science. Vol. 2: 115-144.

${ }^{27}$ Giovanna Maria Dora Dore and Karl D. Jackson. 2014. "Politics is More Difficult than Physics.” In Dore Giovanna Maria Dora Dore, Jae H. Ku, and Karl D. Jackson (Eds). 2014. Incomplete Democracies in the Asia-Pacific. Evidence from Indonesia, Korea, the Philippines and Thailand. London, UK, and New York, NY: Palgrave Macmillan.

${ }^{28}$ Edward Aspinall. 2010. “The Irony of Success.” Journal of Democracy. Vol. 21(2): 20-34.

${ }^{29}$ Richard Rose, William Mishler and Christian Haepfner. 1998. Democracy and Alternatives: Understanding Post-communist Societies. Baltimore: Johns Hopkins University Press

${ }^{30}$ Gabriel Almond and Sidney Verba. 1963. The Civic Culture. Princeton: Princeton University Press.

Russell Dalton and Doh Chull Shin (Eds). 2006. Citizens, Democracy and Markets around the Pacific Rim. Oxford: Oxford University Press.

Inglehart Ronald and Christian Welzel. 2005. Modernization, Cultural Change, and Democracy: The Human Development Sequence. Cambridge: Cambridge University Press

${ }^{31}$ Refer to "Appendix 3. Description of the binary logistic regression models" for details of the countryspecific binary logistic regression models.

${ }^{32}$ See "Appendix 2. Description of the dependent variable operationalization" for the specifics of how the scales for citizens' support for democratic and non-democratic forms of government have been computed for Indonesia, Myanmar and Thailand.

${ }^{33}$ Refer to page 5 in this article for the wording of the four questions.

${ }^{34}$ See "Appendix 3. Description of the binary logistic regression models" for details of the country-specific binary logistic regression models.

${ }^{35}$ T. G. McGee. 1967. The Southeast Asian City. A Social Geography of the Primate Cities of Southeast Asia. New York, NY: Praeger Publications.

${ }^{36}$ Bert Hofman and Kai A. Kaiser. 2002. The Making of the Big Bang and Its Aftermath: A Political Economy Perspective. Paper presented at Can Decentralization Help Rebuild Indonesia? A conference sponsored by the International Studies Program, Andrew Young School of Policy Studies, Georgia State University, May 1-3, 2002, Atlanta, Georgia.

${ }^{37}$ See Table 1 in the article for the complete results of the binary logistic regression model for Indonesia. Also, see the Appendix to the article for a full list of the variables included in the model.

${ }^{38}$ Wilfred Dolfsma and Charlie Dannreuther. 2003. "Subjects and Boundaries: Contesting Social Capitalbased Policies." Journal of Economic Issues. 37: 405-413.

Frane Adam and Borut Roncevic. 2003. 'Social Capital: Recent Debates and Research Trends.' Social Science Information. 42: 155-183.

Lindon J. Robison, A. Allan Schmid, and Marcelo E. Siles. 2002. "Is Social Capital Really Capital?" Review of Social Economy 60: 1-24.

Michael W. Foley and Bob Edwards. 1997. "Escape from Politics? Social Theory and the Social Capital Debate." American Behavioral Scientist.40(5): 550-561.

${ }^{39}$ Pierre Bourdieu. 1986. “The Forms of Capital.” John G Richardson (Ed). 1986. Handbook of Theory and Research for the Sociology of Education, New York, NY: Greenwood Press.

${ }^{40}$ Francis Fukuyama. 1995. Trust: the Social Virtues and the Creation of Prosperity. London, UK: Hamish Hamilton.

${ }^{41}$ Question 50 of the 2011 SAIS Surveys investigate social capital formation, and asked respondents: "I am going to read you a story and then ask you a question about it. The story is about a neighbourhood in this (city, town, or village). A group of families have been living along the same street, which over the years 
has fallen to such despair that it had become nearly unusable. Should each family (SA): i) "do nothing"; ii) "wait for the government to make the repairs"; iii) "personally ask the government to make the repairs'; iv) "repair the road but only in front of my house'; v) "form a neighbourhood association to pressure the government to make the repairs"; vi) "band together with other families in the neighbourhood to repair the entire street"; and vii) "do not know." Respondents" choice for those responses indicating a preference for acting together with other people to repair the street signal their inclination and willingness to participate in, and/or support activities that would build and/or foster the formation of social capital. The Principal investigators for the 2011 SAIS Surveys are aware that many different activities can be seen as supportive/ conducive of social capital formation, and that the topic of social capital can be investigated in many different ways. In choosing the focus and wording of Q50, they followed what has been done in other major national level surveys, such as the World Values Surveys and the Barometer Surveys.

42 Jae H Ku. "Participation, Culture, and Regionalism: Korea's Process of Democratic Consolidation." A dissertation submitted to the Johns Hopkins University. Baltimore, Maryland: May, 2003.

Kwang-Il Yoon and Chong-Min Park 2016. "The Individual-level Implications of Social Capital for Democracy in East Asia." Paper presented at the Asian Barometer Conference on "New Challenges to Asian Democracies in the Age of Globalization, Internet Revolution and Democratic Recession" August 811, 2016, Taipei, Taiwan.

Kim, Sunhyuk. 2000. The Politics of Democratization in Korea: The Role of Civil Society. Pittsburgh, PA: University of Pittsburgh Press.

Fukuyama Francis.1999. "Social Capital and Civil Society." Paper prepared for delivery at the IMF Conference on Second Generation Reforms, October 1, 1999, Washington, District of Columbia.

${ }^{43}$ See Table 1 in the article for the complete results of the binary logistic regression model for Indonesia. Also, see "Appendix 3. Description of the binary logistic regression models" for a complete list of the variables that have been included in the regression model.

${ }^{44}$ See Table 2 in the article for the complete results of the binary logistic regressions. Also, see "Appendix 3. Description of the binary logistic regression models" for a complete list of the variables that have been included in the regression model.

${ }^{45}$ David I. Steinberg (Ed). 2015. Myanmar: The Dynamics of an Evolving Polity. London, U.K.: Lynne Renner Publishers.

Yun-han Chu and Min-hua Huang. 2007. "A Synthetic Analysis of Sources of Democratic Legitimacy." Asian Barometer Working Paper Series No. 41.

International Crisis Group. 2015. "The Myanmar Elections: Results and Implications.” Crisis Group Asia Briefing. Brussels/Yangon.

${ }^{46}$ See Table 2 in the article for the complete results of the binary logistic regressions. Also, see "Appendix 3. Description of the binary logistic regression models" for a complete list of the variables that have been included in the regression model.

${ }^{47}$ Moore Barrington. 1966. Social Origins of Dictatorship and Democracy. Boston, MA: Beacon Press.

William Case (Ed). 2013. Contemporary Authoritarianism in Southeast Asia. Structures, Institutions and Agency. London, UK: Routledge.

${ }^{48}$ Lee Jones. 2014. “The Political Economy of Myanmar's Transition.” Journal of Contemporary Asia. Vol. 44(1): 144-170.

${ }^{49}$ See Table 2 in the article for the complete results of the binary logistic regressions. Also, see "Appendix 3. Description of the binary logistic regression models" for a complete list of the variables that have been included in the regression model.

${ }^{50}$ Ibidem.

${ }^{51}$ Ibidem. 
${ }^{52}$ See Table 3 in the article for the complete results of the binary logistic regressions. Also, see "Appendix 3. Description of the binary logistic regression models" for a complete list of the variables that have been included in the regression model.

${ }^{53}$ Ibidem.

${ }^{54}$ Ibidem.

${ }^{55}$ Arab Barometer I, survey data for Algeria, Kuwait, Jordan, Morocco and Palestine http://www.arabbarometer.org/content/ab-waves.

${ }^{56}$ Arab Barometer II, survey data for Lebanon, Tunisia and Yemen http://www.arabbarometer.org/content/ab-waves.

${ }^{57}$ World Values Survey, Waves 4, 5, and 6 for Turkey - http://www.worldvaluessurvey.org/wvs.jsp

${ }^{58}$ Amaney Jamal and Mark Tessler. 2008. "The Democracy Barometers: Attitudes in the Arab World.” In Tessler Mark (Ed.). 2011. Public Opinion in the Middle East. Survey Research and the Political Orientations of Ordinary Citizens. Bloomington, IN: Indiana University Press, page 108.

${ }^{59}$ Arab Barometer I, survey data for Algeria, Kuwait, Jordan, Morocco and Palestine http://www.arabbarometer.org/content/ab-waves.

${ }^{60}$ Arab Barometer II, survey data for Lebanon, Tunisia and Yemen http://www.arabbarometer.org/content/ab-waves.

${ }^{61}$ World Values Survey, Waves 4, 5, and 6 for Turkey - http://www.worldvaluessurvey.org/wvs.jsp

${ }^{62}$ Marc Tessler. 2000. “Morocco's Next Political Generation.” Journal of North African Studies, 5(1): 126.

${ }^{63}$ Michael Robbins. 2015. "People Still Want Democracy." Journal of Democracy, 26(4): 80-89.

${ }^{64}$ Mark Tessler (Ed.). 2011. Public Opinion in the Middle East. Survey Research and the Political Orientations of Ordinary Citizens. Bloomington, IN: Indiana University Press.

${ }^{65}$ Jeremy Salt. 1999. “Turkey’s Military Democracy.” Current History, 98(625): 72.

${ }^{66}$ Mark Tessler, and Ebru Altinoglu. 2010. "Political culture in Turkey: Connections among attitudes toward democracy, the military and Islam." Democratization, 11(1): 21-50.

${ }^{67}$ Arab Barometer I, and II - http://www.arabbarometer.org/content/ab-waves.

${ }^{68}$ Mark Tessler. 2003. "Do Islamic Orientations Influence Attitudes Toward Democracy in the Arab World? Evidence from Egypt, Jordan, Morocco, and Algeria." International Journal of Comparative Sociology, 2(Spring): 229-49.

${ }^{69}$ Jamal A. Amaney and Mark A. Tessler. 2008. “Attitudes in the Arab World.” Journal of Democracy 19(1): 97-110.

Samuel P. Huntington. 1996. The Clash of Civilizations and the Remaking of the World Order. New York, NY: Simon and Schuster, pp.135-39.

${ }^{70}$ Francis Fukuyama. 1992. The End of History and the Last Man. New York, NY: Avon, pp 45-46.

${ }^{71}$ Bernard Lewis. 1994. The Shaping of the Modern Middle East. New York, NY: Oxford University Press

Elie Kedourie. 1992. Democracy and Arab Political Culture. Washington, D.C.: Washington Institute for Near East Policy.

${ }^{72}$ Arab Barometer I, and II - http://www.arabbarometer.org/content/ab-waves.

${ }^{73}$ Ibid.

${ }^{74}$ Ibid.

${ }^{75}$ S.E. Finer. 1997. The History of Government -3 Volumes. Oxford, UK: Oxford University Press. 
${ }^{76}$ In political science, generally speaking, socialization theory refers to a learning process by which norms and behaviour needed for political systems and civil society to function are passed from one generation to another so that citizens are acquainted with political cultures and their orientations towards politics and civics formed. A variety of agents of socialization facilitate and influence, to different degrees, the formation and/or changes in individuals' political opinions such as family, media, peers, education, religion, race, gender, age and geography. For a treatment and discussion of socialization theory in the realm of political science, see: Ronald Inglehart. 1987. "The Renaissance of Political Culture". American Political Science Review. Vol. 82(3): 1202-1229. Jennifer Glass, Vern L. Bengtson and Charlotte Chorn Dunham. 1986. "Attitude Similarity in Three Generational Families: Socialization, Status Inheritance, or Reciprocal Influence?” American Sociological Review. Vol. 51(5): 685-698. Alex Inkeles and David Smith. 1974. Becoming Modern. Cambridge, MA: Harvard University Press. David Easton. 1968. "The Theoretical Relevance of Political Socialization." Canadian Journal of Political Science / Revue canadienne de science politique. Vol. 1(2):125-146.

${ }^{77}$ Aspinall Edward. 2010. “The Irony of Success.” Journal of Democracy 21(2):20-34. 